\title{
Business Cycles and Investment in Human Capital: International Evidence on Higher Education*
}

\author{
Plutarchos Sakellaris \\ University of Maryland and \\ Board of Governors of the Federal Reserve System \\ Antonio Spilimbergo \\ International Monetary Fund
}

September 1999

\begin{abstract}
We study the effect of economic fluctuations on investment in higher education for a wide range of countries. Our main focus is foreign students who come to the United States to attend university. There is a strong relation between enrollment and the business cycle in the sending country. The cyclical pattern of enrollment is sharply different for two groups of countries. For OECD countries enrollment is countercyclical, whereas for non-OECD countries it is procyclical. At business cycle frequencies, opportunity cost plays a dominant role in explaining enrollment from OECD countries, whereas ability to pay and credit constraints seem more prevalent at non-OECD countries. The results are confirmed using data on domestic enrollment from national sources.
\end{abstract}

*Plutarchos Sakellaris, Department of Economics, University of Maryland, College Park, MD 20742 (plutarch@electra.umd.edu); Antonio Spilimbergo, Research Department, IMF, 700 19th St., NW, Washington, DC 20431 (aspilimbergo@imf.org). This paper was presented at the Carnegie-Rochester Conference Series on Public Policy, and was written while the first author was visiting the Industrial Output Section of the Board of Governors of the Federal Reserve System. We would like to thank Antonio Ciccone, Alexander Hoffmaister, Norman Morin and seminar participants at the IMF, the World Bank, the University of Maryland, and the University of Rochester for helpful discussions and Ivan Guerra for research assistance. The views expressed here do not represent those of the staff of the Federal Reserve System, the IMF, or their Boards. 


\section{Introduction}

The cyclical properties of investment in human capital had been left largely unexplored until recently. Some new work, however, stresses the importance of examining these properties. Dellas and Sakellaris (1995) argue that in the U.S. there is significant substitution between education and competing labor activities during the business cycle. They provide evidence that the propensity of 18- to 22-year-old high school graduates to enroll in college is significantly countercyclical.

The direction and size of the cyclical component to enrollment can be described as the confluence of two counteracting factors: the opportunity cost, and the ability to pay, both of which move in a procyclical manner. The Dellas and Sakellaris findings for the U.S. point to the conclusion that at business cycle frequencies the opportunity cost element of the enrollment decision is more important than the ability to pay element. Credit constraints, that is, are relatively less important for the cyclical properties of investment in higher education in the U.S. In section 2, we review more thoroughly the relevant empirical literature.

Can one treat these U.S. results as general and representative of other countries too? As countries differ in labor market institutions, educational institutions and policies, and financial development, it seems important to caution against such a generalization. There should be no presumption that the relative importance of opportunity cost and ability to pay (or their cyclical components) should be the same across countries.

This paper studies the effect of the business cycle on investment in higher education for a wide range of countries. To achieve this goal it is imperative to have consistent, and long, time series data for a diverse set of countries. We have addressed these concerns by assembling data on a measure of educational investment that comes from a single collecting organization. The data definitions and quality are consistent across a wide range of countries. We focus on foreign students who come to attend university in the U.S. (for undergraduate or graduate work). These data are published annually by the Institute for International Education and are collected as a census of U.S. higher education institutions. Further details on this and other data used in this paper is provided in section $3 .{ }^{1}$

\footnotetext{
${ }^{1}$ Ideally, we would have total enrollment data in higher education regardless of whether the studies took
} 
Our results, contained in section 4, establish a strong relation between U.S. enrollment and the business cycle in the sending country in 1961 to 1992 . However, both the size and the direction of this cyclical behavior differ sharply for two groups of countries. For the OECD countries enrollment is countercyclical. This is consistent with the U.S. domestic enrollment evidence discussed in the beginning of this introduction. However, for nonOECD countries the pattern is strongly procyclical. Furthermore, the effect of aggregate shocks in these countries is clearly permanent.

This striking divergence in pattern cannot be accounted fully by disparities in the level or inequality of income and, likely, points to the importance of institutions, hard as they may be to quantify, in explaining the cyclical properties of higher education. OECD countries have better developed financial systems, lower aggregate output volatility, and, perhaps, better higher education systems compared to the rest of the countries in our sample. They may also have better functioning labor markets allowing an easier transition to (and from) work and, thus, making the (effective) opportunity cost to education more pronounced and more cyclical.

The robustness of our findings for U.S. enrollment is confirmed by examining also the joint behavior of output, domestic enrollment, and foreign enrollment in a tri-variate VAR system. In addition, we find that domestic enrollment displays a countercyclical pattern in OECD countries as opposed to a procyclical one in non-OECD countries. We provide some concluding remarks in section 5 .

\section{Connection to the Literature}

Traditional human capital models conclude that the main factors influencing individual decisions to acquire a university education are: the rate of return to university education, the cost of the education, and family background characteristics, a very important one of which is family income. ${ }^{2}$ There exists by now a large body of empirical work on the demand for higher education and its relationship to the above economic variables, which

place at home or abroad. In addition, we would like to have variables that pertain to the rate of return on higher education such as education wage premium, or the quality of education. Unfortunately, such data are not consistent, or not available for many countries.

${ }^{2}$ See, for example, Becker (1993), and Schultz (1971). 
we will not attempt to survey here. The results of this literature are broadly consistent with the predictions of the standard models, such as those of Becker (1993), Ben-Porath (1967), and Mincer (1958). Surprisingly, this empirical literature has paid no attention to cyclical aspects of the demand for higher education.

Dellas and Sakellaris (1995) point out how an extension of the Ben-Porath model with cyclical economic conditions can describe the cyclical behavior of the demand for schooling as the confluence of two counteracting factors. To exposit their point simply, we present here a bare-bones two-period version of the model. Individuals choose the fraction of nonleisure time to devote to education, $u$, so as to maximize

$$
U=w_{1}(1-u) H_{1}+w_{2} \frac{1}{R} F\left(u, H_{1}\right),
$$

where $w_{t}$ is the rental rate of human capital at time $t, R$ is the gross real interest rate, $H$ is the stock of human capital, and $F$ is the concave human capital (education) production function. ${ }^{3}$ Individuals choose investment in education so that

$$
w_{1} H_{1}=w_{2} \frac{1}{R} \frac{\partial F\left(u, H_{1}\right)}{\partial u} .
$$

Human capital investment, that is the enrollment decision, is increasing in $w_{2} / w_{1}$. If at time 1 the economy is in a temporarily low state of activity, a recession, whereas at time 2 it will be in a high state of activity, an expansion, then it is likely that $w_{2} / w_{1}$ is temporarily large. Human capital investment, then, is countercyclical due to the countercyclical nature of the opportunity cost of education.

The above model, however, does not allow for the possibility of binding credit constraints. Tuition fees and other large direct costs to education together with the inability to borrow using future earnings as collateral could lead to such constraints. If the borrowing ability of an individual depends on her income or that of her family then the ability to pay for education may be procyclical. This seems quite plausible for low net worth individuals and families. Ability-to-pay considerations, then, would tend to make schooling procyclical. ${ }^{4}$ Thus, from a conceptual point, it is not clear what should be the direction

\footnotetext{
${ }^{3}$ This simple model assumes no uncertainty, two periods of lifetime, linear utility, fixed non-leisure time, no direct cost to education, no physical or financial assets, uniform learning ability, independence of the rental rate and the level of human capital, and possible completion of education in one time period. See the Dellas and Sakellaris (1995) paper for a relaxation of these restrictions.

${ }^{4}$ See Dellas and Sakellaris (1995) for more on the role of credit constraints in the enrollment decision.
} 
and size of the cyclical component to educational investment. Both of these attributes need to be established through empirical examination. ${ }^{5}$

There seems to be quite a bit of anecdotal evidence that the demand for higher education is countercyclical in the U.S. For example, admissions officers at MBA programs often mention the phenomenon of rising enrollment rates during recessions. Curiously, there was no empirical evidence on this fact until recently.

Some empirical studies focused on cross-sectional analysis of youths' schooling decisions and the local labor market conditions. Their results were inconclusive. Manski and Wise (1983) found that the local unemployment rate was not significantly related to college application. Also looking at four-year colleges, Venti and Wise (1983) found that the local unemployment rate was not significantly related to the probability of attendance. Blakemore and Low (1983) found that the local unemployment rate was negatively related to the probability of enrollment in a higher education institution though things were less clear when they disaggregated by type of institution. Since the data used for these studies, however, do not contain a time series dimension they cannot address the issue of the cyclicality of higher education.

Kane (1994) used data from a time series of cross sections of 18- and 19-year-old youths from 1973 through 1988 in order to examine secular trends in college enrollment of black high school graduates. On closer reading, however, the study contains a result related to the present discussion of cyclicality of education. Kane finds that the local unemployment rate is not significantly related to the probability of college enrollment for either blacks or whites. ${ }^{6}$

Dellas and Sakellaris (1995) address directly the issue of the direction and size of the cyclical component to schooling. They use a time series of cross sections of 18 - to 22-yearold high school graduates from 1968 through 1988 to create a time series of propensity to enroll in university that is purged of the influence of individual characteristics. ${ }^{7}$ This series

\footnotetext{
${ }^{5}$ We have presumed that other significant determinants of the enrollment decision, such as (net) tuition and fees, do not have significant cyclical components.

${ }^{6}$ See the results in the third columns of Tables 3 and 4 respectively (pages 894 and 896). These estimations control for local fixed effects, which is necessary in order to remove the variation in the unemployment rate that is not due to cyclical economic activity.

${ }^{7}$ The source of data is the same as Kane's (1994): the October CPS, which asks individuals whether they are enrolled in school. Note, however, that the sample of Dellas and Sakellaris is longer than Kane's
} 
displays a strong, countercyclical pattern. For the period of 1968-1988 a one percentage point increase in the unemployment rate is associated with about a $2 \%$ increase in college enrollment. Simulations suggest that cyclical fluctuations in aggregate economic activity may have caused significant swings in enrollment. For instance, in October 1982, when the unemployment rate stood about 1.9 points higher than 12 months earlier, their estimates indicate that college enrollment would have been lower by about 232,000 were it not for the recession. This number is substantial when contrasted with the reduction in employment between October of 1981 and October of 1982 of about 1.163 million, even though it does not include enrollment of older individuals.

Betts and McFarland (1995) independently examined the impact of the business cycle on enrollment at public 2-year colleges in the U.S during 1969 to 1985 . They found that an increase in the unemployment rate by 1 percentage point is associated with a rise in full-time attendance of about 4.5 percent. $^{8}$

These results show that opportunity-cost considerations are more important than abilityto-pay considerations for individuals' enrollment decisions in the United States, at least at business cycle frequencies. Of course, there should be no presumption that this pattern holds for all other countries. In particular, one might argue that a country's level of development affects the extent to which individuals face credit constraints or how well high school graduates are incorporated in the labor market search process.

\section{Data Description}

Our main variable of analysis is the number of students at the tertiary education level who study in the United States disaggregated by sending country. Ideally, we would use the total number of students enrolled in tertiary education, both domestically and abroad. In practice, the quality of domestic education varies substantially from country to country so that international comparisons are difficult to make. For this reason, we provide two sets of results. In the first set we only consider foreign enrollment in the U.S., which has the advantage of controlling for quality of education and consistency of data across

and covers a broader segment of the population eligible for higher education.

${ }^{8}$ Their sample consists of observations on enrollment in a panel of two-year public colleges from 1969 to 1985 . 
countries. In the second set of results we also consider data on domestic enrollment. It was not possible to construct a series on total number of foreign students in a consistent manner across sending countries. ${ }^{9}$ We argue below that we do not lose much information by concentrating on foreign enrollment in the U.S.

In order to have an idea of the relevance of the United States as a destination for students at the tertiary level of education, we report in Table 1 the distribution of foreign students according to the sending continents and the main destination countries in 1993.

The United States represents by far the most important destination country, having 34.5 percent of all non-U.S. foreign students. The role of the United States is especially large in Latin America and in Asia. In 1993, the United States accounted for over 80 percent of total foreign students originating from Central American and Caribbean countries (with the exception of Haiti and Nicaragua), and for about 50 percent for the rest of Latin America. Among Asian countries, the United States was the destination country for over 50 percent of the students who studied abroad from Indonesia, Korea, Saudi Arabia, India, Thailand, Philippines, Myanmar, and Kuwait. Predictably, the United States plays a much smaller role in the French-speaking African countries, whose students go predominantly to France, and in Europe and Oceania, whose students prefer to study in neighboring countries.

The United States has been the most important recipient country in the last forty years since data are available; moreover, the share of United States as a recipient country has remained constant at around 33 percent at least since the beginning of the 1960 s. For the countries with available data on the share of foreign students going to the U.S. is roughly the same in 1965 and in 1993, showing that there has not been dramatic change in the distribution of students abroad in the last thirty years. We conclude that the analysis of foreign student flows to the United States provides a reliable picture of cyclical movements in tertiary education enrollment abroad.

We use data on the number of foreign non-immigrant students in U.S. universities. These are published in various issues of Open Doors, the annual publication of the Institute of International Education (IIE). We have applied some adjustments to make the series

\footnotetext{
${ }^{9}$ The Statistical Yearbooks by UNESCO provide data on students abroad but many entries are missing. Moreover, the data are collected by the destination countries, which use different and, some times, inconsistent definitions of foreign students.
} 
consistent. We describe the adjustments in the Data Appendix. This data set is unique in providing the only available data set to our knowledge which keeps track of number of non-immigrant foreign students in the U.S. for such a long period of time. Moreover, it contains other useful information such as their academic level, field of study, and source of financing for some years.

Figure 1 shows the total number of non- immigrant students in the US from 1959 to 1997. ${ }^{10}$ The number of foreign students in the United States increased steadily in the period considered from 48486 to 481280 , at an average annual growth rate of 6.0 percent. This rate of growth was higher than the average GDP growth during the period and was comparable with trade growth, which averaged 5.5 percent during the same period. With the exception of 1971 , when the number of foreign students declined by 3 percent, the rate of growth was always positive. The number of foreign students has increased also in relation to total enrollment in the United States: from 1.4 percent in 1959 to 3.3 percent in 1997. Figure 2 shows the annual rate of growth of foreign students and the rate of growth of U.S. real GDP. Two periods can be distinguished. Before 1981, the rate of growth of students is much more volatile and seems correlated with lagged GDP growth. After 1981, the rate of growth of students is more stable and is not correlated with GDP growth. In particular, the long expansions of the 1980s and of the 1990's are associated with relatively low growth rates of foreign students.

While the total number of students has grown steadily since 1959, there are remarkably different regional dynamics. Figure 3a shows the total number of students from South and Central America. Before 1982, there was steady growth interrupted only by a slight decrease at the beginning of the 1970s. After the outbreak of the debt crisis in 1982, the number of students declined and stayed at lower levels up to the end of the decade. Only after 1992 did growth resume. Even more dramatic is the behavior of the oil producing countries. ${ }^{11}$ Figure $3 \mathrm{~b}$ shows the students coming from oil producing countries. The effect of oil price

\footnotetext{
${ }^{10}$ Note that throughout the paper we use the year of the Fall semester to indicate the academic year. So, for instance, 1959 means academic year 1959-1960.

${ }^{11}$ The oil producing countries countries are: Saudi Arabia, Iran, Iraq, Trinidad \& Tobago, Mexico, Venezuela, Indonesia, Libya, Nigeria, Kuwait. We exclude United Kingdom and Norway because they are industrialized countries. Note that Iran was one of the most important sending countries in the $1970 \mathrm{~s}$ and the flow of students decreased quite abruptly after the Islamic revolution. Even excluding Iran, the picture for OPEC countries does not change substantially.
} 
movements is evident. Before 1972, there was a steady but moderate increase in the number of students in the United States. After 1973, there was a dramatic increase so that the number of students more than quintupled by the end of the decade. At the beginning of the 1980s, the number of students plummeted after the revolution in Iran and the fall in the oil price. Figure $3 \mathrm{c}$ shows the numbers for students coming from Asia. ${ }^{12}$ The growth of students from this region is impressive especially during the 1970s and the 1980s. During the 1990s, enrollment stabilized due to a marked decline of students from India, China, Malaysia, and Taiwan. Figure 3d tracks European students. The smooth growth since 1973 masks a big change in the composition of students. Western European students increased steadily since 1973 and reached a plateau in 1991 when former communist countries picked up quite dramatically. Figure 3e reports the student for Africa. The dynamic here is totally driven by Nigeria which is an oil producer. As in the case of other oil producers, the number of students peaked in the early 1980s and fell dramatically in the late 1990s.

IIE collects also data on the distribution of students by academic level. Table 2 shows that almost half of the foreign students in the United States are undergraduates. Note that Asian students are concentrated mostly in graduate programs unlike students from other regions of the world.

\section{Results}

Our baseline data are annual observations for 74 countries on students enrolled in the U.S. and real GDP per capita adjusted for Purchasing Power Parity. Hereafter, we will refer to the number of students enrolled in the U.S. as "enrollment" for short even though it is distinct from students enrolled at home universities ("domestic enrollment") or in other countries. We will also refer to the GDP per capita measure as "output". Since we do not have early observations on output for a few countries, our panel data set is unbalanced.

We perform diagnostic tests on all variables to detect the presence of unit roots. We use both traditional augmented Dickey-Fuller (ADF) tests on individual series and a test proposed by Levin and Lin (1993), which extends the ADF test to exploit the panel structure

\footnotetext{
${ }^{12}$ Asia includes all Asian countries with the exception of Middle East countries and the Central Asian Republics created in 1991. The majority of Middle Eastern countries enter in the oil producing countries sample.
} 
of our data. The methodology proposed by Levin and Lin (1993) tests for the presence of a unit root in each individual time series against the alternative hypothesis that each series is stationary, allowing the other parameters to vary freely across individuals. For foreign enrollment, we cannot reject the null hypothesis of unit root for all the countries except for Uganda, Kenya, and Panama at the 5 percent confidence level. The results are confirmed using the Levin and Lin methodology. ${ }^{13}$ We have similar results for output. ${ }^{14}$

Since we fail to reject the null hypothesis of a unit root in the log-level of output or enrollment, we proceed to specify our basic regression in log-differences:

$$
\Delta \log \left(E_{i t}\right)=\alpha+\Phi(L) \Delta \log \left(E_{i, t-1}\right)+\Psi(L) \Delta \log \left(Y_{i t}\right)+\epsilon_{i t}
$$

where $E_{i t}$ is U.S. enrollment and $Y_{i t}$ is output of country $i$ at time $t, \Phi(L)$ and $\Psi(L)$ are finite-order polynomials in non-negative powers of the lag operator $L$.

As a preliminary pass at the data we ran a "between" regression of the average enrollment growth on average output growth. ${ }^{15}$ The estimate of the slope coefficient was $0.37(0.17)$ with an $R^{2}$ of $0.03 .^{16}$ At first look, then, there is some evidence of a positive long-run relationship between the growth in enrollment and the growth in output.

We go on to exploit the time series dimension of our panel and try to estimate the dynamic relationship between enrollment growth and output growth. Table 3 reports dynamic regressions. We allow for common aggregate shocks through the inclusion of year dummies. All regressions also control for idiosyncratic country effects (except for column 1). This specification is consistent with country-specific time trends as well as year dummies in the level of enrollment. The longest period of observation (after forming lags) is 1961 to $1992 .^{17}$

From the results in column (2) it is clear that the dynamic relationship is quite rich. The contemporaneous observation for output is not significant. This seems reasonable since the students counted in the census enrolled in their university around August for the fall

\footnotetext{
${ }^{13}$ In both methodologies, we select optimal lag lengths for each series and allow for a trend.

${ }^{14}$ We also check whether the first differences of all variables are stationary. We can reject the hypothesis of a unit root both in the individual regressions for the majority of the countries and in the panel test.

${ }^{15}$ Both were calculated after removing year means.

${ }^{16}$ The standard error (in parentheses) is robust to heteroskedasticity.

${ }^{17}$ It is well-known that fixed effects models are inconsistent with lagged dependent variables for short panels. This should not be a problem here since our time dimension is relatively large.
} 
semester whereas output reflects economic conditions for a few months past that through the end of the year. The first five lags of output are strongly positive and significant. This probably reflects the fact that enrollment at any given year includes several different cohorts of arrival: at least four for the undergraduate students; more for doctoral students.

The inclusion of several different cohorts of arrival in our enrollment number complicates our analysis a bit. Presumably, the cohort that is just arriving is more sensitive to recent economic conditions than older cohorts. This would be true, for example, if there were some fixed cost (in terms of time and money) to initiating an overseas education. Examples of such costs would be transportation expenses, aptitude tests such as the TOEFL, the SAT, and the GRE, the application procedure and so on. Unfortunately, we do not have data on different arrival cohorts so our results may be tainted by aggregation bias.

The coefficients on the lagged dependent variables are significant, indicating that shortrun and long-run dynamics may look quite different. ${ }^{18}$ After dropping insignificant lag variables, we arrive at our preferred specification in column (3) of Table 3 . Enrollment growth responds positively to output growth. The short-run elasticity is 0.18 . The response in the long run is considerably stronger with an elasticity of 1.07 , that is, a 1-percent increase in a country's output is associated with a permanent increase in the country's U.S. enrollment of about 1 percent. ${ }^{19}$

The countries in our sample display higher volatility of enrollment than of output. The standard deviation of output growth ranges from 14.9 percent (Uganda) to 1.3 percent (France) with a mean of 4.9 percent. The standard deviation of enrollment growth ranges from 35.5 percent (Somalia) to 6 percent (Colombia) with a mean of 14 percent. Furthermore, countries that have volatile output growth tend to have volatile enrollment growth (the correlation coefficient is 0.51 ).

An interesting question is whether recessions have a stronger impact than expansions on enrollment. We could not find any evidence of that. There is some indication, however, that the adjustment to a recessionary shock is faster.

\footnotetext{
${ }^{18}$ For all estimates reported in this paper the conditions for stability of the process defined in equation (3) are satisfied.

${ }^{19}$ The $R^{2}$ in (3) is 0.31 . After removing the effect of the country dummies, the $R^{2}$ falls to 0.22 . The coefficients of the lags of output are not significantly different from a common value of 0.167 . We proceed without imposing this restriction as it does not affect the remainder of our analysis.
} 


\subsection{Heterogeneity}

A matter of concern is that in a pool of countries as varied as that in our sample it may be the case that allowing for different intercepts (through country dummies) may not be adequate to capture the potential heterogeneity. Various aspects of labor market institutions, educational systems, and financial development differ by country and affect the sensitivity of young individuals' educational decisions to aggregate conditions. In order to address this concern we split the countries into two groups by various criteria and estimate equation (3) separately. Table A1 (in the Appendix) contains group classification information.

OECD countries.

First, we split the countries according to membership in the OECD. ${ }^{20}$ Table 4 contains the results. The behavior of OECD countries is quite distinct from non-OECD countries. In the former group, enrollment decreases significantly after the shock but it is not clear that the effect is permanent. This countercyclical pattern of enrollment behavior is in sharp contrast with that of non-OECD countries. The latter group displays strong positive, and persistent, response. The long run elasticity of enrollment is 1.09 .

OECD countries seem distinct in several aspects that are relevant to educational decisions. As a group they have better developed financial systems, lower aggregate output volatility, and, perhaps, better higher education systems compared to the rest of the countries in our sample. They may also have better functioning labor markets allowing an easier transition to (and from) work and, thus, making the (effective) opportunity cost to education more pronounced and more cyclical. It is also likely that the ability-to-pay element is less cyclical in the OECD countries due to higher level, more equal distribution, and lower volatility of income per family. The above aspects of OECD countries would tend to make the opportunity cost considerations more important than ability to pay ones, and the enrollment decision countercyclical.

Two important aspects of OECD countries are that they are relatively rich and they display less inequality in income distribution. We address the possibility that these elements distinguish these countries as having a population of potential foreign students that are less

\footnotetext{
${ }^{20}$ We do not include in the OECD group, however, the Czech Republic, Hungary, Korea, Mexico, and Poland, which joined in the 1990's.
} 
likely to face constraints on their ability to pay for this education.

\section{Income Inequality:}

We split countries by the degree of income inequality as captured by the average Gini coefficient. $^{21}$ We form three groups of roughly equal size: countries with high income inequality, low inequality, and those without inequality data. The results are contained in Table 4 and are broadly consistent across groups. The pattern is procyclical for all groups and the long run elasticity to a shock in output growth is the lowest in the low-inequality group, 0.64 , compared with 1.38 in the high-inequality and 1.31 in the residual group. Interestingly, the low-inequality group contains all OECD countries except for France and Turkey, for which we found earlier significant countercyclical and less persistent pattern of response. This leads us to conclude that the group of low-inequality countries contains some members with highly procyclical patterns of enrollment. The overall effect is dampened by the presence of OECD countries in it.

To test the robustness of these conclusions we split the sample according to a similar criterion: the percentage of income accruing to the top quintile of population (in terms of income). The results are roughly similar.

Initial income level.

We split according to the average level of countries' GDP per capita in 1960 to $1965 .^{22}$ The results in Table 5 show broad consistency across high- and low-income countries with the elasticity in both cases around unity. This despite the fact that every OECD country except for Turkey belong in the high-income group. ${ }^{23}$ On the other hand, some of the countries lumped together with the OECD countries as high-income ones seem quite different in terms of labor market, financial, and educational institutions. In addition, their economic development in the three decades that followed the 1960 s presented wide disparities. Iran underwent a revolution that altered its world economic standing significantly and also affected immensely its relations with the U.S. including educational exchange. Some Latin countries such as Mexico and Argentina faced very volatile conditions in the 1980s. OPEC countries such as Saudi Arabia and Venezuela also faced much volatility due to oil

\footnotetext{
${ }^{21}$ This is available for most countries in 5 -year intervals between 1965 and 1985 . The cutoff level for the split is the mean across countries of 41.3 .

${ }^{22}$ The cutoff was the mean across countries.

${ }^{23}$ Including Turkey in this group has no discernible impact on the results, however.
} 
price movements. It is difficult to think of all these countries together with the OECD as a homogeneous group. We interpret the strong procyclical pattern in high-income countries as mainly reflecting the behavior of non-OECD countries.

\section{Educational Attainment and Other Patterns.}

Continuing on our search for diversity among countries, we examine whether the level of educational attainment at the beginning of the sample is related to countries' cyclical enrollment behavior. We classify countries according to the proportion of their population of age over 25 years that had completed secondary education in $1965 .^{24}$ This gives an indication of the relative size of the population eligible to continue to higher education. The results for the two groups (as seen in Table 5) show that the procyclical nature of enrollment is much more pronounced in the "less educated" group, which displays a longrun elasticity of 1.29. The "more educated" group displays insignificant association. Almost all OECD countries are part of the high educational attainment group. ${ }^{25}$

We also split the sample according to the prevalence of the U.S. higher education system in educating the country's students who venture abroad. In particular we form the ratio of enrollment in the U.S. over that in the rest of the world by sending country for $1965 .{ }^{26}$ The countries that depend more heavily on the U.S. for foreign education have a higher long run elasticity, 1.40 versus 0.53 for the other countries. However, the latter group does not appear so homogeneous in terms of the response to output. It contains all but five of the OECD countries, for which we have seen already that the pattern is countercyclical. ${ }^{27}$

To summarize, we tried to divide the sample of countries in many different ways, in order to uncover differences in the pattern of response of enrollments to domestic conditions. The one characteristic that emerges as significant is country membership in the OECD. Non-OECD countries display strongly procyclical patterns of enrollment whereas OECD

\footnotetext{
${ }^{24}$ The cutoff is the median value.

${ }^{25}$ The correlation between this measure and initial output is 0.64. Interestingly, Austria, Portugal, Spain, and Great Britain are classified in the lower educational attainment group. This raises concerns about the validity of our classification variable, which comes from UNESCO.

${ }^{26}$ The correlation with the analogous measure in 1993 is quite high at 0.61 . The countries for which the allocation of students abroad changed drastically during these three decades were Iran and South Africa, whose political relations with the U.S. changed dramatically, Ireland, for the citizens of which a U.K. education became much cheaper after joining the E.U., El Salvador, Honduras, Indonesia, and Sri Lanka.

${ }^{27}$ The OECD countries that are in the upper half in terms of dependence on the U.S. for foreign education are: Australia, Canada, Denmark, Ireland, and New Zealand.
} 
countries display countercyclical and less pronounced variations in enrollment. Observable country characteristics go part of the way toward explaining this disparity. ${ }^{28}$

Our interpretation of the finding is that OECD countries have better functioning labor markets allowing young individuals to make easier transitions between work and education, and, thus, making the (effective) opportunity cost to education more cyclical. It is also likely that the ability-to-pay element is less cyclical in the OECD countries due to higher level and lower volatility of income per family and of national resources devoted to support foreign study.

\subsection{Credit constraints}

In section (2), we broadly characterized the determinants of the enrollment decision in terms of opportunity-cost and ability-to-pay variables. It seems that the strong procyclical pattern of enrollment for non-OECD countries points toward a dominant role for abilityto-pay considerations in determining the cyclical behavior of enrollment. To be precise, this evidence is broadly consistent with the joint hypothesis of (binding) credit constraints in obtaining a U.S. university education and of significant cyclical movements in the degree to which these constraints bind. ${ }^{29}$

In order to test properly for the cyclical importance of credit constraints we would need variables that fulfill three conditions: 1) they capture the gap between the cost of pursuing a U.S. education and the available (internal or external) financing for it, 2) display both time-series and cross-country variation, and 3 ) are available for a large set of countries and a long period of observation. Unfortunately, we do not have such data at our disposal. We do, nonetheless, proceed to use what we do have to examine the issue.

Fluctuations in the real exchange rate offer an opportunity to assess the responsiveness of educational investment to the price of education and the degree to which individuals from outside the U.S. have access to financing in the U.S. (or elsewhere). The relevant price is

\footnotetext{
${ }^{28}$ In addition to the characteristics reported above we also examined the volatility of a country's output, how synchronized its business cycle is to that of the U.S., and a measure of financial depth (relative size of financial intermediaries). We have not examined, however, some other worthy candidates, such as the premium to higher education or the quality of primary and secondary education.

${ }^{29} \mathrm{Flug}$ et al. (1998) provide country evidence that average enrollment in secondary education is negatively related to income volatility and lack of financial development (as measured by financial depth). They interpret this as evidence for binding credit constraints.
} 
the tuition and other fees at a U.S. university expressed in domestic currency. Drops in the real exchange rate reflect increases in the price of acquiring a U.S. education under the assumption that the individuals on the margin are not internationally diversified in their asset portfolio. They also intensify credit constraints under the assumption that marginal individuals have limited access to borrowing. These two effects both lead to a decrease in foreign enrollment. Thus, it is not clear whether a drop in enrollment after a devaluation is due to tighter credit constraints or to a change in relative prices. Strictly speaking, the analysis in this subsection is not a test of credit constraints but rather of the hypothesis that marginal individuals do not hold internationally diversified portfolios (of non-human and human assets), or have limited access to borrowing. Under the alternative hypothesis, individuals would respond to real exchange rate changes by altering the international allocation of their portfolio but not their enrollment decision.

We have obtained data on real exchange rates for various years between 1975 and 1995 for a small set of countries in our sample. Given the spotty availability of this data (obtained from the World Bank) we could not include it as another explanatory variable in our dynamic regression (3). We resort to a simpler way of examining the dynamic association between exchange rate and enrollment movements. We identify episodes of extreme movement in the real exchange rate as a depreciation of more than 20 percent or an appreciation of more than 20 percent. We then look at what happened on average to enrollment growth during and after these episodes, that is we run

$$
\Delta \log \left(E_{i, t+j}\right)=\alpha+\beta_{1 j} \text { Depreciation }_{i t}+\beta_{2 j} \text { Appreciation }_{i t}+\Psi_{j}(L) \Delta \log \left(Y_{i, t+j}\right)+\epsilon_{i, t+j}
$$

for $j=0,1,2$, and 3, where Depreciation $_{i t}$ and Appreciation $_{i t}$ are dummy variables, as defined above. Table 6 contains the average effects, $\beta_{1}$ and $\beta_{2}$, after controlling for contemporaneous and three lags of output growth. ${ }^{30}$ These results show that large shocks to the real exchange rate have significant effects on enrollment of the predicted sign. Furthermore, there seems to be an asymmetry in these responses. The effect of a depreciation is

\footnotetext{
${ }^{30}$ There are 24 episodes of depreciation (of average magnitude -43 percent), and 23 episodes of appreciation (of average magnitude 30 percent) out of a total 425 observations. Both exchange rate and enrollment growth rates are expressed as deviations from their country and year means. The reference event is: "Movements in the real exchange rate less than 20 percent in absolute value." Including a fourth, or fifth lag of output growth in the regressions does not affect the results.
} 
especially strong, is spread roughly over three years and seems to be highly persistent. In contrast, the effect of an appreciation is immediate. ${ }^{31}$

To sum up, the results of this simple, reduced-form test are quite strong and point toward individuals responding to changes in the price of education in a manner consistent with limited access to international education loans and grants. The strength of the case for credit constraints depends on the degree of substitution between foreign and domestic education. The lower is this substitutability the more likely it is that the changes we have documented in U.S. enrollment are due to credit constraints rather than price changes. ${ }^{32}$

\subsection{VAR Evidence}

So far we have focused on the response of students enrolled in the U.S. to the sending country's macroeconomic shocks. While this is necessary in order to have homogeneous data over time and over countries, this analysis has the shortcoming of ignoring the response of domestic higher education enrollment to a GDP shock. In this section, we use data on domestic enrollment in tertiary education and consider the joint dynamic behavior of output, domestic enrollment, and foreign enrollment. Before proceeding further, we caution the reader that these data are gathered by individual nations' statistical agencies without trying to coordinate on a consistent definition across countries. Thus, using it for international comparisons may not be problem-free but should be instructive, none the less.

We use a VAR system that allows us to trace the dynamic responses to GDP shocks over time:

$$
\begin{aligned}
\Delta \ln \left(Y_{i t}\right) & =\alpha_{i 10}+\alpha_{11}(L) \Delta \ln \left(Y_{i t-1}\right)+\alpha_{12}(L) \Delta \ln \left(D_{i t-1}\right)+\alpha_{13}(L) \Delta \ln \left(E_{i t-1}\right)+\delta_{1 t}+\varepsilon_{i 1 t} \\
\Delta \ln \left(D_{i t}\right) & =\alpha_{i 20}+\alpha_{21}(L) \Delta \ln \left(Y_{i t-1}\right)+\alpha_{22}(L) \Delta \ln \left(D_{i t-1}\right)+\alpha_{23}(L) \Delta \ln \left(E_{i t-1}\right)+\delta_{2 t}+\varepsilon_{i 2 t} \\
\Delta \ln \left(E_{i t}\right)= & \alpha_{i 30}+\alpha_{31}(L) \Delta \ln \left(Y_{i t-1}\right)+\alpha_{32}(L) \Delta \ln \left(D_{i t-1}\right)+\alpha_{33}(L) \Delta \ln \left(E_{i t-1}\right)+\delta_{3 t}+\varepsilon_{i 3 t},
\end{aligned}
$$

where $E_{i t}$ is U.S. enrollment, $D_{i t}$ is domestic enrollment, and $Y_{i t}$ is output of country $i$ at time $t$, and $\alpha_{r s}$ are finite-order polynomials in non-negative powers of the lag operator $L$.

\footnotetext{
${ }^{31}$ We have tested for robustness by defining the cutoff for extreme changes as 15 percent, instead. In this case, there were 37 episodes of depreciation (of average magnitude and 35 episodes of appreciation. The qualitative nature and the significance of the effects did not change, though the size was smaller.

${ }^{32}$ We assume that individuals on the margin of enrolling in a U.S. university are deciding between that and domestic enrollment rather than work or time off.
} 
We allow for country dummies in all equations as countries in our sample have very different demographic and enrollment dynamics over the period considered. We include year dummies to control for factors specific to the U.S. (for example, availability of fellowships or U.S. economic conditions) that could change the number of foreign students enrolled in the United States. We include five lags for each variable. Since the typical duration of tertiary level studies is four to five years, the economic shocks of the previous five years can have an impact on the total number of students enrolled today. Moreover, we cannot reject that the fifth lag of each equation is statistically significant. ${ }^{33}$

We specify our system in differences rather than in levels. We could not reject the hypothesis of a unit root in the three system variables and, a priori, do not expect a cointegrating relationship to hold among them. ${ }^{34}$ Based, then, on the results by Phillips (1998) that impulse responses and forecast error decompositions are inconsistent at long horizons in unrestricted VARs with some non-stationary variables, we prefer to estimate the above system in differences rather than in levels. We also estimated the system in levels and found no substantial differences in the short term dynamics.

The system is estimated over the period 1965 to 1992 (after taking differences and up to 5 lags) because we do not have data on domestic enrollment in the sixties. For some countries the period of coverage is smaller because domestic enrollment was not available. As explained in the Data Appendix, we made some adjustments to the domestic enrollment data to correct discontinuities. ${ }^{35}$ As we will see below, our results for foreign enrollment are largely similar to those we obtained in the univariate regressions based on (3) and with a different sample.

Figure 4 presents the impulse responses of GDP, domestic and foreign enrollment to one standard deviation shock to GDP, domestic, and foreign enrollment growth. We orthogonalize the errors according to the Choleski decomposition with the ordering GDP,

\footnotetext{
${ }^{33} \mathrm{As}$ a robustness test, we tried the same system using three to six lags. The results for the impulse responses do not change substantially.

${ }^{34}$ For domestic enrollment, we fail to reject the unit root hypothesis for every country individually and the results are confirmed by the Levin and Lin test. Results for the other two variables were reported above.

${ }^{35}$ The list of the countries we use in the VAR corresponds to the list of countries for which domestic enrollment is available - see the Data Appendix.
} 
domestic students, and finally foreign students. ${ }^{36}$ For ease of interpretation, we graph the cumulative response of the three variables. Finally, we include confidence bands equal to two standard deviations. ${ }^{37}$

The first row of Figure 4 presents the responses of GDP, domestic and foreign enrollment to an output shock. In response to a positive GDP shock of 5.2 percent, the average standard deviation, the number of domestic enrollment increases by 0.6 percent, while the foreign enrollment increases only by 0.5 percent. For the following five years, the cumulative responses of domestic and foreign students rise. In the long run, domestic students rise by 2.7 percent, and foreign students by 7.1 percent. Note that the impact effect is bigger for domestic enrollment, while the long run effect is much bigger for foreign students. ${ }^{38}$ The second row of Figure 4 presents the responses to a shock in the rate of growth of domestic enrollment. The effect on output is statistically insignificant, while the effect on foreign enrollment is slightly negative contemporaneously, but insignificant thereafter.

We run the same VAR in the two sub-samples, OECD and non-OECD countries, which displayed marked differences in the univariate analysis. Figures 5 and 6 show the impulse response graphs. A comparison of the two graphs reveals important differences. First, the average shock to GDP growth for OECD countries, 1.9 percent, is much smaller than the shock for non-OECD countries, 6.1 percent . Second, the short-run responses of domestic and foreign enrollments are positive and significant in non-OECD countries, while in OECD countries the response is negative and significant for foreign enrollment but not significantly different from zero for domestic enrollment. Moreover, the responses are persistent over time for non-OECD countries while they are not for the OECD countries.

\footnotetext{
${ }^{36}$ The covariance matrix of the system is:

2.66

$0.38 \quad 5.12$

$0.34 \quad 0.39$

$0.39 \quad 16.10$

* $\frac{1}{1000}$. Given that, even without orthogonalization, the elements on the diagonal

are an order of magnitude higher than the off-diagonal elements, the impulse responses are not sensitive to the the method of orthogonalization. In other words, innovations are practically uncorrelated with the contemporaneous shocks to the other variables.

${ }^{37}$ The standard deviations were calculated by performing a Monte Carlo simulation with 500 draws.

${ }^{38}$ The results on the permanent nature of the shock to students depend on estimating our system in difference rather than in level. However, the results that foreign enrollment is significantly higher for a long time after a shock to GDP is robust to estimating in levels rather than in differences. For instance, foreign enrollment is still seven percent higher after 12 years of a GDP shock of 4 percent in the estimation in levels.
} 
39 It is interesting to note also that the results show no evidence of substitution between domestic and foreign education.

Regarding variance decomposition, we find that only a small share of the variance in domestic enrollment growth is explained by output growth in the short run. Even in the long run (after 12 years) output growth explains only 1.2 percent of the variance for nonOECD countries and 2.3 percent for OECD countries. In the case of foreign enrollment, output plays a bigger role in the non-OECD countries; it accounts for 6.8 percent of the variance on foreign enrollment growth after twelve years. In contrast, in OECD countries the contribution of output growth is a bit less than 4 percent even in the long run. These results pose the challenge of finding additional variables that can explain enrollment growth variation, especially for OECD countries. ${ }^{40}$

\section{Conclusion}

We have studied the effect of economic fluctuations on the accumulation of human capital in a wide range of countries. There is a systematic relationship between domestic business cycles and enrollment in higher education. This effect is especially strong for education abroad in U.S. institutions, a component of human capital investment that is especially important for many developing countries. There may not be good substitutes for such education at home (after adjusting for quality), especially for graduate studies and for technology-related studies (whether graduate or undergraduate). Citizens with higher education attained abroad may be important for technology adoption in the home country, particularly where the technology gap with the developed world is large.

Of course, these foreign students affect their country's human capital stock and technology adoption mainly to the extent that they repatriate after the end of their studies or temporary employment. However, the wide availability of opportunities to work in the U.S. or elsewhere after the completion of studies leads, undoubtedly, to brain drain from home

\footnotetext{
${ }^{39}$ The results are broadly confirmed in a VAR in levels rather than in differences. The only difference is that the response of domestic enrollment for OECD countries is not significantly different from zero.

${ }^{40}$ When we dropped the 1960s data from our sample (keeping 1970-1992), we found that the contribution of output growth to the various variances went up by a factor of 2 to 3 . This indicates that aggregate economic conditions were more important determinants of enrollment after the 1960s, a decade described probably by secular changes in tertiary education for many countries.
} 
countries. Our findings open the possibility of important cyclical aspects of world-wide human capital migration, which deserve attention in future work.

The finding that there is strong substitution between education, or, perhaps, skills acquisition in general, and other economic activities over the cycle compels us to ask an important question. Does human capital investment influence the properties of the business cycle itself? Perli and Sakellaris (1998) argue that the answer is: yes. They augment a standard, one-sector neoclassical model with a formal education sector and show that the cyclical behavior of educational activity imparts a strong propagation mechanism to this model. Shocks to the productivity of the goods-producing sector induce reallocation of hours among leisure, work, and education, which, in turn, leads to persistent movements in aggregate output. ${ }^{41}$

There are some pressing issues that need to be addressed in future work. Whereas, we have documented movements into and out of higher education during the business cycle we have not been able to describe the magnitude of transitions among labor market states. To accomplish this we need reliable international data on employment and labor force participation. Finally, a word about on-the-job training. This constitutes a very large part of investment in human capital and its cyclical properties have received even less attention than those of education. Clearly, future work should be directed at analyzing this.

\footnotetext{
${ }^{41}$ The key condition for this two-sector model to display persistence is that there be low substitutability between raw labor and human capital in the production of human capital.
} 


\section{Data Appendix}

Foreign Students in the U.S. A foreign non-immigrant student is defined as anyone who is enrolled in courses at institutions of higher education (from the undergraduate level up), and is not a U.S. citizen, an immigrant (permanent resident), or a refugee. ${ }^{42}$

Since 1919, the Institute for International Education (IIE) has conducted an annual census of foreign students in the United States. The data collected in the course of these years is the primary source of information on the historical pattern of foreign students in the U.S.. For this reason, it has been used both for internal purposes to assist the U.S. government in the administration of the Fullbright Graduate Fellowship Program, and by international organizations such as UNESCO.

The IIE has changed its methodology of collecting data over the years. During the last forty years there were two major changes: the introduction of statistical samples instead of total population counts, and changes in the treatment of immigrant students. We make two adjustments to make our data consistent over time. ${ }^{43}$

The first adjustment corrects a change in the data collection methodology. Before 1974, IIE used to conduct an annual census asking all U.S. institutions of higher learning to fill out a form with detailed information on each foreign student enrolled. Given the size of the questionnaire, some institutions did not answer at all. The increasing non-response rate created a problem of sample selection in the beginning of the $1970 \mathrm{~s}^{44}$ In response to this problem, IIE started using a sampling methodology in 1974 instead of trying to have a census of the entire foreign students. ${ }^{45}$

\footnotetext{
${ }^{42}$ These institutions correspond to level 5,6 , and 7 ISCED classification used by UNESCO. Foreign students can have different visas: $\mathrm{F}$ (the standard full time student visa), $\mathrm{H}$ (temporary VISA given to workers/students performing services unavailable in the U.S.), $\mathbf{J}$ (exchange-visitor visa), $M$ (for students in vocational courses). Note that some of these visas are available also to non-students so that they cannot be used as a proxy for students.

${ }^{43}$ Beyond these two major adjustments, we made some changes when countries changed names, or split.

${ }^{44}$ The census provides a reasonable approximation of actual number of students if the response rate is high as it was at the beginning of the 1960s when around 90 percent of the institutions answered. As the complexity of the questionaire increased, the response rate declined steadily to below 70 percent.

${ }^{45}$ After 1974, IIE sent three questionaires to each institution. The first questionaire asked just for basic information such as the total number of foreign students. The other two questionaires asked for more detailed individual information such as the nationality and funding. Due to the simplicity of the first survey, the number of institutions responding has increased considerably, allowing a more precise estimation of the foreign students. The country-by-country breakdown for the institutions which respond just to stage one - reporting only the total number of foreign students - is extrapolated from the other institutions for
} 
The second adjustment was to account for changes in the treatment of immigrant students. Before 1966, IIE defined a foreign student as a "person who comes to the United States expressly to study and states his intention of returning home afterwards." Between 1966 and 1973, IIE changed the definition to include all foreign students regardless of their visa classification or of their stated intention to remain in the United States. After 1973, IIE switched back to the previous definition which did not include the immigrant students. We have subtracted the immigrant students from the total number of foreign students for the years between 1966 and 1973 in order to create homogeneous series. ${ }^{46}$

\section{Sample selection criteria for univariate regressions of U.S. enrollment:}

Among almost 200 countries for which some information is available on foreign students in the U.S., we have selected countries which satisfied the following criteria: (a) there are data for every year from 1960 to 1992; (b) in each year the number of students is more than 40; and (c) data on GDP per capita from the Summers-Heston tables is available continuously from 1970 to 1992 .

The list of these countries which satisfy the three criteria is: Argentina, Australia, Austria, Barbados, Belgium, Bolivia, Brazil, Canada, Chile, Colombia, Costa Rica, Cyprus, Denmark, Dominican Republic, Ecuador, Egypt, El Salvador, Ethiopia, Fiji, Finland, France, Germany, Ghana, Greece, Guatemala, Guyana, Haiti, Honduras, Iceland, India, Indonesia, Iran, Ireland, Israel, Italy, Jamaica, Japan, Jordan, Kenya, Korea, Liberia, Mexico, Morocco, Myanmar, Nepal, Netherlands, New Zealand, Nicaragua, Nigeria, Norway, Panama, Paraguay, Peru, Philippines, Portugal, Saudi Arabia, Sierra Leone, Somalia, South Africa, Spain, Sri Lanka, Sweden, Switzerland, Syria, Tanzania, Thailand, Trinidad \& Tobago, Tunisia, Turkey, Uganda, United Kingdom, Uruguay, Venezuela, Zimbabwe.

which more detailed information is available. Note that while this is a more accurate approximation for the total number of foreign students, it is based on the assumption that the composition by nationality is the same in the reporting and in the non-reporting institutions. To have an idea of the approximation, among the 2758 accredited institutions for higher education surveyed in 1994-95, 2684 responded. Among the responding ones, 167 did not have foreign students, while 2517 had foreign students. Finally, among the respondents with foreign students 87 percent provided breakdown by nationality. IIE has changed often the methodology through which it extrapolates the number of foreign students for each nationality. For this reason, we have used the original unextrapolated data to create our extrapolated figures which are consistent over the entire period.

${ }^{46}$ While the number of immigrant students disaggregated by country is available between 1970 and 1974 , only the total number is available between 1966 and 1969. We use the average proportion of immigrant students in the second period to extrapolate the number of immigrant students in the previous period. 
Domestic enrollment in tertiary education. We use the number of students enrolled in: (a) programs leading to an award not equivalent to a first university degree (5 ISCED level); (b) programs leading to a first university degree or equivalent qualifications (6 ISCED level); (c) programs leading to a post-graduate university degree or equivalent qualifications ( 7 ISCED level). ${ }^{47}$ The data come from national sources and are collected by UNESCO and published in the UNESCO Statistical Yearbook. They are also available from the UNESCO data site: http://unescostat.unesco.org/ for the years after 1970. In order to assure comparability across time and across countries, we drop some countries for which it was impossible to reconstruct a coherent series. The countries we drop are: Barbados, Fiji, Guyana, Haiti, Jamaica, Paraguay, Sierra LEone, Somalia, South Africa, Sri Lanka, Uruguay, and Zimbabwe. We made some adjustments in the data for some of the remaining countries in order to avoid evident discontinuity.

Income per capita. We use real GDP per capita in constant dollars (chain-indexed) expressed in international prices (base 1985). We obtained these from the NBER electronic version of the Penn World data, also known as the Summers-Heston data.

Financial Depth is the M2 to GDP ratio. The data source is the World Bank World Development Indicators 1998 CD-ROM.

Gini and quintile distribution. We use the Gini coefficients and the distribution of income from the Deininger and Squire (1996) data set.

Secondary education. We use the proportion of people above 25 with completed highschool or secondary education. The original data on enrollment flows from the UNESCO Yearbooks has been added over time to obtain data on educational attainment by Barro and Lee (1996).

Real effective exchange rate. We use the real exchange rate as calculated by the World Bank and available in the World Development Indicators 1998 CD-ROM.

Total foreign students abroad. The data source is the UNESCO Statistical Yearbook.

Finally, the OECD group includes countries which joined OECD before 1992: Australia, Austria, Belgium, Canada, Denmark, Finland, France, Germany, Greece, Iceland, Ireland,

\footnotetext{
${ }^{47}$ By selecting these categories we assure compatibility with our data on the foreign students in the United States.
} 
Italy, Japan, Netherlands, New Zealand, Norway, Portugal, Spain, Sweden, Switzerland, Turkey, United Kingdom, and United States. 


\section{REFERENCES}

Barro, Robert J. and Lee, Jong-Wha (1996). International Measures of Schooling Years and Schooling Quality. American Economic Review Papers and Proceedings 86, 2: 218-223.

Becker, G. S., (1993). Human Capital, 3rd edition. Chicago: The University of Chicago Press.

Ben-Porath, Y., (1967). The Production of Human Capital and the Life Cycle of Earnings. Journal of Political Economy, 75, 4, Part I: 352-365.

Blakemore, A. E. and Low, S. A., (1983). A Simultaneous Determination of Post-High School Education Choice and Labor Supply. Quarterly Review of Economics and Business, 23: 81-92.

Deininger, K. and Squire, L., (1996). Measuring Income Inequality: A New Data Base. World Bank Economic Review.

Dellas, H. and Sakellaris, P., (1995). On the Cyclicality of Schooling: Theory and Evidence. University of Maryland Working Paper 95-12.

Flug, K., Spilimbergo, A. and Wachtenheim, E, (1998). Investment in education: do economic volatility and credit constraints matter? Journal of Development Economics, 55: 465-481.

IIE (Various issues). Open Doors: Report on International Education Exchange. New York: Institute of International Education.

Kane, T., (1994). College Entry by Blacks since 1970: The Role of College Costs, Family Background, and the Returns to Education. Journal of Political Economy, 102: 878-911.

Levin, A. and Lin, C., (1993). Unit Root Tests in Panel Data: Asymptotic and FiniteSample Properties. Federal Reserve Board Working Paper.

Manski, C. and Wise, D. A., (1983). College Choice in America. Cambridge, Mass.: Harvard University Press.

Mincer, J., (1958). Investment in Human Capital and Personal Income Distribution. Journal of Political Economy, 66, 4: 281-302. 
Perli, R. and Sakellaris, P., (1998). Human Capital Formation and Business Cycle Persistence. Journal of Monetary Economics, 42: 67-92.

Phillips, P. C. B., (1998). Impulse Response and Forecast Error Variance Asymptotic in nonstationary VARs. Journal of Econometrics, 83: 21-56.

Schultz, T. W., (1971). Investment in Human Capital. New York.

UNESCO (Various years). Statistical Yearbook.

Venti, S. and Wise, D. A., (1983). Individual Attributes and Self Selection of Higher Education. Journal of Public Economics, 21: 1-32. 
Table 1:

Foreign students by destination country

\begin{tabular}{lrrrrrrr}
\hline \hline & \multicolumn{7}{c}{ Destination (as percentage share) } \\
\hline Sending Continents & Total & U. S. & France & Germany & U. K. & Russia & Japan \\
Africa & 169046 & 12.2 & 43.6 & 4.7 & 5.0 & 3.4 & 0.2 \\
Asia & 648074 & 45.4 & 3.0 & 7.7 & 5.6 & 6.9 & 6.4 \\
Europe & 344992 & 17.3 & 10.4 & 13.7 & 11.7 & 8.9 & 0.2 \\
South and Central America & 77021 & 59.1 & 7.9 & 5.2 & 3.8 & 2.2 & 0.9 \\
Oceania & 16013 & 24.1 & 1.1 & 1.1 & 5.5 & 0.0 & 1.6 \\
World Total & 1303564 & 34.5 & 10.4 & 8.6 & 6.9 & 6.3 & 3.4 \\
\hline \hline
\end{tabular}

Source: UNESCO Statistical Yearbook (1995) and authors' calculations.

Table 2:

Distribution by Academic Level (year 1996/97)

\begin{tabular}{lrrrr}
\hline \hline & \multicolumn{4}{c}{ Academic Level (as percentage share) } \\
\hline Sending Continents & \multicolumn{1}{c}{ Total } & Undergraduate & Graduates & Other \\
\hline Africa & 22078 & 62.4 & 33.4 & 4.2 \\
Asia & 260743 & 44.7 & 47.4 & 7.9 \\
Europe & 68315 & 51.6 & 40.7 & 7.8 \\
South and Central America & 49592 & 61.9 & 31.5 & 6.5 \\
Oceania & 3690 & 57.3 & 38.1 & 4.7 \\
World Total & 457984 & 49.7 & 42.8 & 8.6 \\
\hline \hline
\end{tabular}

Notes: The source is Open Doors (1997). "Other" includes intensive English language, non-degree, and practical training. 
Table 3:

U.S. Enrollment Regressions

\begin{tabular}{|c|c|c|c|c|c|c|}
\hline & (1) & & (2) & & (3) & \\
\hline "Enrollment $(\mathrm{t}-1)$ & $\begin{array}{c}0.061 \\
(0.021)\end{array}$ & *** & $\begin{array}{c}0.043 \\
(0.022)\end{array}$ & * & $\begin{array}{c}0.058 \\
(0.021)\end{array}$ & ** \\
\hline Enrollment $(\mathrm{t}-2)$ & $\begin{array}{c}0.160 \\
(0.021)\end{array}$ & $* *$ & $\begin{array}{c}0.144 \\
(0.021)\end{array}$ & $* *$ & $\begin{array}{c}0.147 \\
(0.021)\end{array}$ & ** \\
\hline Output(t) & $\begin{array}{c}0.034 \\
(0.052)\end{array}$ & & $\begin{array}{c}0.054 \\
(0.055)\end{array}$ & & - & \\
\hline Output(t-1) & $\begin{array}{c}0.159 \\
(0.052)\end{array}$ & $* *$ & $\begin{array}{c}0.180 \\
(0.055)\end{array}$ & $* *$ & $\begin{array}{c}0.177 \\
(0.055)\end{array}$ & $* *$ \\
\hline Output(t-2) & $\begin{array}{c}0.114 \\
(0.053)\end{array}$ & * & $\begin{array}{c}0.133 \\
(0.055)\end{array}$ & * & $\begin{array}{c}0.126 \\
(0.055)\end{array}$ & * \\
\hline Output(t-3) & $\begin{array}{c}0.135 \\
(0.053)\end{array}$ & ** & $\begin{array}{c}0.163 \\
(0.055)\end{array}$ & $* *$ & $\begin{array}{c}0.184 \\
(0.055)\end{array}$ & ** \\
\hline Output(t-4) & $\begin{array}{c}0.185 \\
(0.053)\end{array}$ & $* *$ & $\begin{array}{c}0.212 \\
(0.055)\end{array}$ & $* *$ & $\begin{array}{c}0.204 \\
(0.055)\end{array}$ & ** \\
\hline Output(t-5) & $\begin{array}{c}0.128 \\
(0.053)\end{array}$ & * & $\begin{array}{c}0.154 \\
(0.055)\end{array}$ & $* *$ & $\begin{array}{c}0.154 \\
(0.055)\end{array}$ & ** \\
\hline Output(t-6) & $\begin{array}{c}0.026 \\
(0.053)\end{array}$ & & $\begin{array}{c}0.061 \\
(0.055)\end{array}$ & & - & \\
\hline Output(t-7) & $\begin{array}{c}-0.048 \\
(0.053) \\
\end{array}$ & & $\begin{array}{c}-.021 \\
(0.055) \\
\end{array}$ & & - & \\
\hline $\begin{array}{l}\text { Observations } \\
R^{2}\end{array}$ & $\begin{array}{l}2105 \\
0.29\end{array}$ & & $\begin{array}{l}2211 \\
0.31\end{array}$ & & $\begin{array}{l}2211 \\
0.31\end{array}$ & \\
\hline
\end{tabular}

NOTES: $\Delta \log \left(E_{i t}\right)=\alpha+\Phi(L) \Delta \log \left(E_{i, t-1}\right)+\Psi(L) \Delta \log \left(Y_{i t}\right)+\epsilon_{i t}$, where $E_{i t}$ is U.S. enrollment and $Y_{i t}$ is PPP-adjusted GDP per capita of country i at time t. All specifications include year dummies, and columns (2) and (3) include country dummies as well. Data sample is listed in the Data Appendix. Standard errors are in parentheses. Significance at the 5 percent level: ${ }^{*}$; at the 1 percent level: ${ }^{* *}$. 
Table 4:

Sample Splits by Country Characteristics

\begin{tabular}{|c|c|c|c|c|c|c|c|c|c|c|}
\hline & OECD & & non-OECD & & UNEQUAL & & EQUAL & & MISSING & \\
\hline$\overline{E(t-1)}$ & $\begin{array}{c}-.168 \\
(0.039)\end{array}$ & ** & $\begin{array}{c}0.080 \\
(0.026)\end{array}$ & *** & $\begin{array}{c}0.083 \\
(0.033)\end{array}$ & ** & $\begin{array}{c}0.082 \\
(0.034)\end{array}$ & * & $\begin{array}{c}-.027 \\
(0.047)\end{array}$ & \\
\hline$E(t-2)$ & $\begin{array}{c}0.054 \\
(0.039)\end{array}$ & & $\begin{array}{c}0.159 \\
(0.026)\end{array}$ & $* *$ & $\begin{array}{c}0.189 \\
(0.033)\end{array}$ & $* *$ & $\begin{array}{c}0.120 \\
(0.034)\end{array}$ & $* *$ & $\begin{array}{c}0.141 \\
(0.047)\end{array}$ & $* *$ \\
\hline $\mathrm{Y}(\mathrm{t}-1)$ & $\begin{array}{c}-.416 \\
(0.163)\end{array}$ & ** & $\begin{array}{c}0.202 \\
(0.061)\end{array}$ & $* *$ & $\begin{array}{c}0.055 \\
(0.094)\end{array}$ & & $\begin{array}{c}0.269 \\
(0.086)\end{array}$ & $* *$ & $\begin{array}{c}0.246 \\
(0.111)\end{array}$ & \\
\hline $\mathrm{Y}(\mathrm{t}-2)$ & $\begin{array}{c}0.260 \\
(0.165)\end{array}$ & & $\begin{array}{c}0.108 \\
(0.061)\end{array}$ & & $\begin{array}{c}0.130 \\
(0.094)\end{array}$ & & $\begin{array}{c}0.076 \\
(0.086)\end{array}$ & & $\begin{array}{c}0.174 \\
(0.111)\end{array}$ & $* *$ \\
\hline $\mathrm{Y}(\mathrm{t}-3)$ & $\begin{array}{c}-.235 \\
(0.165)\end{array}$ & & $\begin{array}{c}0.192 \\
(0.061)\end{array}$ & $* *$ & $\begin{array}{c}0.210 \\
(0.094)\end{array}$ & $*$ & $\begin{array}{c}-.034 \\
(0.084)\end{array}$ & & $\begin{array}{c}0.342 \\
(0.111)\end{array}$ & $* *$ \\
\hline$Y(t-4)$ & $\begin{array}{c}0.279 \\
(0.160)\end{array}$ & & $\begin{array}{c}0.184 \\
(0.062)\end{array}$ & $* *$ & $\begin{array}{c}0.178 \\
(0.096)\end{array}$ & & $\begin{array}{c}0.188 \\
(0.085)\end{array}$ & * & $\begin{array}{c}0.295 \\
(0.111)\end{array}$ & $* *$ \\
\hline$Y(t-5)$ & $\begin{array}{c}-.038 \\
(0.155)\end{array}$ & & $\begin{array}{c}0.147 \\
(0.062)\end{array}$ & $*$ & $\begin{array}{c}0.417 \\
(0.098)\end{array}$ & $* *$ & $\begin{array}{c}0.008 \\
(0.085)\end{array}$ & & $\begin{array}{c}0.106 \\
(0.114)\end{array}$ & $*$ \\
\hline $\begin{array}{l}\text { Observations } \\
R^{2}\end{array}$ & $\begin{array}{l}681 \\
0.35\end{array}$ & & $\begin{array}{l}1530 \\
0.24\end{array}$ & & $\begin{array}{l}841 \\
0.26\end{array}$ & & $\begin{array}{l}822 \\
0.25\end{array}$ & & $\begin{array}{l}548 \\
0.26\end{array}$ & \\
\hline
\end{tabular}

NOTES: See the notes to Table 6. E (t) denotes U.S. enrollment growth, and Y(t) denotes output growth. OECD/non-OECD denotes country membership before 1990 .

UNEQUAL/EQUAL/MISSING: classification based on Gini coefficient of income inequality averaged over 1965 to 1985 . The cutoff level is the mean over countries. Countries with missing data denoted by MISSING. The $R^{2}$ was calculated after removing the contribution of country effects. 
Table 5:

Sample Splits by Country Characteristics

\begin{tabular}{|c|c|c|c|c|c|c|c|c|c|c|c|c|}
\hline & RICH & & POOR & & $\mathrm{EDUC}=0$ & & $\mathrm{EDUC}=1$ & & INUS $=1$ & & INUS $=0$ & \\
\hline $\bar{E}(\mathrm{t}-1)$ & $\begin{array}{c}-.003 \\
(0.030)\end{array}$ & & $\begin{array}{c}0.091 \\
(0.030)\end{array}$ & "** & $\begin{array}{c}0.093 \\
(0.032)\end{array}$ & $\overline{* *}$ & $\begin{array}{c}-.131 \\
(0.032)\end{array}$ & *** & $\begin{array}{c}0.032 \\
(0.032)\end{array}$ & & $\begin{array}{c}0.062 \\
(0.032)\end{array}$ & "* \\
\hline $\mathrm{E}(\mathrm{t}-2)$ & $\begin{array}{c}0.167 \\
(0.030)\end{array}$ & $* *$ & $\begin{array}{c}0.139 \\
(0.030)\end{array}$ & $* *$ & $\begin{array}{c}0.143 \\
(0.031)\end{array}$ & $* *$ & $\begin{array}{c}0.138 \\
(0.032)\end{array}$ & $* *$ & $\begin{array}{c}0.215 \\
(0.032)\end{array}$ & $* *$ & $\begin{array}{c}0.103 \\
(0.031)\end{array}$ & $* *$ \\
\hline $\mathrm{Y}(\mathrm{t}-1)$ & $\begin{array}{c}0.139 \\
(0.094)\end{array}$ & & $\begin{array}{c}0.183 \\
(0.072)\end{array}$ & ** & $\begin{array}{c}0.190 \\
(0.077)\end{array}$ & * & $\begin{array}{c}.045 \\
(0.100)\end{array}$ & & $\begin{array}{c}0.111 \\
(0.088)\end{array}$ & & $\begin{array}{c}0.139 \\
(0.079)\end{array}$ & \\
\hline $\mathrm{Y}(\mathrm{t}-2)$ & $\begin{array}{c}0.237 \\
(0.095)\end{array}$ & $* *$ & $\begin{array}{c}0.104 \\
(0.072)\end{array}$ & & $\begin{array}{c}0.145 \\
(0.077)\end{array}$ & $*$ & $\begin{array}{c}0.104 \\
(0.100)\end{array}$ & & $\begin{array}{c}0.232 \\
(0.088)\end{array}$ & $* *$ & $\begin{array}{c}-.007 \\
(0.080)\end{array}$ & \\
\hline $\mathrm{Y}(\mathrm{t}-3)$ & $\begin{array}{c}0.209 \\
(0.095)\end{array}$ & $*$ & $\begin{array}{c}0.164 \\
(0.072)\end{array}$ & * & $\begin{array}{c}0.210 \\
(0.077)\end{array}$ & & $\begin{array}{c}0.063 \\
(0.100)\end{array}$ & & $\begin{array}{c}0.295 \\
(0.089)\end{array}$ & $* *$ & $\begin{array}{c}0.053 \\
(0.079)\end{array}$ & \\
\hline$Y(t-4)$ & $\begin{array}{c}0.160 \\
(0.095)\end{array}$ & & $\begin{array}{c}0.189 \\
(0.073)\end{array}$ & $* *$ & $\begin{array}{c}0.240 \\
(0.078)\end{array}$ & $* *$ & $\begin{array}{c}0.107 \\
(0.100)\end{array}$ & & $\begin{array}{c}0.189 \\
(0.089)\end{array}$ & $*$ & $\begin{array}{c}0.151 \\
(0.079)\end{array}$ & * \\
\hline $\mathrm{Y}(\mathrm{t}-5)$ & $\begin{array}{c}0.093 \\
(0.094)\end{array}$ & & $\begin{array}{c}0.142 \\
(0.073)\end{array}$ & & $\begin{array}{c}0.193 \\
(0.078)\end{array}$ & $* *$ & $\begin{array}{c}-.022 \\
(0.101)\end{array}$ & & $\begin{array}{c}0.220 \\
(0.089)\end{array}$ & $*$ & $\begin{array}{c}0.108 \\
(0.080)\end{array}$ & \\
\hline $\mathrm{N}$ & 1097 & & 1114 & & 1007 & & 1011 & & 1057 & & 1010 & \\
\hline$R^{2}$ & 0.26 & & 0.22 & & 0.22 & & 0.27 & & 0.26 & & 0.24 & \\
\hline
\end{tabular}

NOTES: See the notes to Table 6. $\mathrm{E}(\mathrm{t})$ denotes U.S. enrollment growth, and $\mathrm{Y}(\mathrm{t})$ denotes output growth. Countries are classified by whether they rank above or below the group mean (or median). The relevant country characteristics are defined below. RICH/POOR: Average level of GDP per capita from 1960 to 1965. EDUC: Proportion of population of age over 25 that had completed secondary education in 1965. INUS: proportion enrolled in university in the U.S. of total university enrollment abroad by country nationals in 1965 . The $R^{2}$ was calculated after removing the contribution of country effects. 
Table 6:

Effects of Real Exchange Rate Movements on U.S. Enrollment

\begin{tabular}{||l|cc|c||}
\hline \hline & Depreciation & Appreciation & $R^{2}$ \\
\hline \hline $\mathrm{E}(\mathrm{t})$ & -0.076 & 0.042 & 0.03 \\
& $(0.026)$ & $(0.025)$ & \\
$\mathrm{E}(\mathrm{t}+1)$ & -0.061 & 0.001 & 0.02 \\
& $(0.025)$ & $(0.025)$ & \\
& & & \\
$\mathrm{E}(\mathrm{t}+2)$ & -0.040 & 0.019 & 0.02 \\
& $(0.024)$ & $(0.024)$ & \\
& & & \\
$\mathrm{E}(\mathrm{t}+3)$ & -0.004 & 0.013 & 0.02 \\
& $(0.023)$ & $(0.022)$ & \\
\hline \hline
\end{tabular}

NOTES: Each row reports results of the specification:

$\Delta \log \left(E_{i, t+j}\right)=\alpha+\beta_{1 j}$ Depreciation $_{i t}+\beta_{2 j}$ Appreciation $_{i t}+\Psi_{j}(L) \Delta \log \left(Y_{i, t+j}\right)+\epsilon_{i, t+j}$, for $j=0,1,2$, and 3, where Depreciation $i t$ and Appreciation $_{i t}$ are dummy variables taking the value of 1 if the real exchange rate decreased or increased by more than 20 percent respectively. Displayed are the average effects, $\beta_{1}$ and $\beta_{2}$, (and their standard errors) after controlling for contemporaneous and three lags of output growth. The total number of observations is 425 . 
Table A1:

List of countries and their characteristics

\begin{tabular}{|c|c|c|c|c|c|c|c|c|}
\hline COUNTRY & 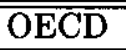 & UNEQUAL & RICH & EDUC & INUS & HICORRUS & HIVAR & HIDEPTH \\
\hline Argentina & 0 & . & $\overline{1}$ & $\overline{1}$ & $\overline{1}$ & $\overline{\overline{0}}$ & 1 & 1 \\
\hline Australia & 1 & 0 & 1 & 1 & 1 & 1 & 0 & 1 \\
\hline Austria & 1 & . & 1 & 0 & 0 & 1 & 0 & 1 \\
\hline Barbados & 0 & 1 & 1 & 1 & 1 & 1 & 0 & 1 \\
\hline Belgium & 1 & 0 & 1 & 1 & 0 & 1 & 0 & 1 \\
\hline Bolivia & 0 & 1 & 0 & 1 & 0 & 1 & 0 & 0 \\
\hline Brazil & 0 & 1 & 0 & 1 & . & 0 & 1 & 1 \\
\hline Canada & 1 & 0 & 1 & 1 & 1 & 1 & 0 & $\mathbf{1}$ \\
\hline Chile & 0 & 1 & 1 & 1 & 1 & 1 & 1 & 0 \\
\hline Colombia & 0 & 1 & 0 & 1 & 1 & 1 & 0 & 0 \\
\hline Costa Rica & 0 & 1 & 1 & 0 & 1 & 1 & 0 & 0 \\
\hline Cyprus & 0 & . & 1 & 1 & . & 1 & 1 & 1 \\
\hline Denmark & 1 & 0 & 1 & 1 & 1 & 1 & 0 & 1 \\
\hline Dominican Rep. & 0 & 1 & 0 & 0 & 1 & 0 & 1 & 0 \\
\hline Ecuador & 0 & . & 0 & 0 & 1 & 0 & 1 & 0 \\
\hline Egypt & 0 & 0 & 0 & . & 0 & 0 & 0 & 1 \\
\hline El Salvador & 0 & 1 & 0 & 0 & 1 & 1 & 0 & 0 \\
\hline Ethiopia & 0 & . & 0 & . & 1 & 0 & 0 & 1 \\
\hline Fiji & 0 & 1 & 1 & 1 & 0 & 0 & 1 & 1 \\
\hline Finland & 1 & 0 & 1 & 1 & 0 & 0 & 0 & 1 \\
\hline France & 1 & 1 & 1 & 1 & 0 & 1 & 0 & 1 \\
\hline Germany & 1 & 0 & 1 & 1 & 0 & 1 & 0 & 1 \\
\hline Ghana & 0 & 0 & 0 & 0 & 0 & 0 & 1 & 0 \\
\hline Greece & 1 & 0 & 1 & 1 & 0 & 1 & 0 & 1 \\
\hline Guatemala & 0 & 1 & 0 & 0 & 1 & 1 & 0 & 0 \\
\hline Guyana & 0 & . & 0 & 0 & . & 0 & 1 & 1 \\
\hline Haiti & 0 & . & 0 & 0 & . & 1 & 0 & 0 \\
\hline Honduras & 0 & 1 & 0 & 0 & 1 & 1 & 0 & 0 \\
\hline Iceland & 1 & . & 1 & 1 & 0 & 1 & 1 & 0 \\
\hline India & 0 & 0 & 0 & 0 & 1 & 0 & 1 & 0 \\
\hline Indonesia & 0 & 0 & 0 & 0 & 0 & 0 & 0 & 0 \\
\hline Iran & 0 & 1 & 1 & 0 & 1 & 0 & 1 & . \\
\hline Ireland & 1 & 0 & 1 & 1 & 1 & 1 & 0 & 1 \\
\hline Israel & 0 & . & 1 & 1 & 1 & 0 & 0 & 1 \\
\hline Italy & 1 & 0 & 1 & 1 & 0 & 1 & 0 & 1 \\
\hline Jamaica & 0 & 1 & 0 & 0 & 1 & 1 & 1 & 1 \\
\hline Japan & 1 & 0 & 1 & 1 & 1 & 1 & 0 & 1 \\
\hline Jordan & 0 & 0 & 0 & 0 & 0 & 0 & 1 & 1 \\
\hline Kenya & 0 & 1 & 0 & 0 & 0 & 1 & 1 & 0 \\
\hline Korea & 0 & 0 & 0 & 1 & 1 & 1 & 1 & 0 \\
\hline Liberia & 0 & . & 0 & 0 & 1 & 1 & 1 & 0 \\
\hline
\end{tabular}


Table A1(continued):

List of countries and their characteristics

\begin{tabular}{|c|c|c|c|c|c|c|c|c|}
\hline COUNTRY & OECD & UNEQUAL & RICH & EDŪC & INUS & HICORRUS & HIVAR & HIDEPTH \\
\hline Mexico & 0 & $\overline{1}$ & 1 & $\overline{0}$ & $\overline{11}$ & 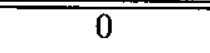 & 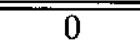 & $\overline{0}$ \\
\hline Morocco & 0 & 0 & 0 & - & 0 & 0 & 1 & 1 \\
\hline Myanmar & 0 & . & 0 & 0 & 0 & 0 & 1 & 0 \\
\hline Nepal & 0 & 0 & 0 & 0 & . & 1 & 1 & 0 \\
\hline Netherlands & 1 & 0 & 1 & 1 & 0 & 1 & 0 & 1 \\
\hline New Zealand & 1 & 0 & 1 & 1 & 1 & 1 & 0 & 0 \\
\hline Nicaragua & 0 & . & 0 & 0 & 1 & 0 & 1 & 1 \\
\hline Nigeria & 0 & 0 & 0 & . & 1 & 0 & 1 & 0 \\
\hline Norway & 1 & 0 & 1 & 1 & 0 & 1 & 0 & 1 \\
\hline Panama & 0 & 1 & 0 & 1 & 1 & 0 & 1 & 0 \\
\hline Paraguay & 0 & . & 0 & 0 & 1 & 0 & 1 & 0 \\
\hline Peru & 0 & 1 & 1 & 1 & . & 0 & 1 & 0 \\
\hline Philippines & 0 & 1 & 0 & 1 & 1 & 0 & 0 & 0 \\
\hline Portugal & 1 & 0 & 1 & 0 & 0 & 0 & 1 & 1 \\
\hline Saudi Arabia & 0 & . & 1 & . & 1 & 0 & 1 & 0 \\
\hline Sierra Leone & 0 & 1 & 0 & 0 & 0 & 0 & 1 & 0 \\
\hline Somalia & 0 & . & 0 & . & 0 & 0 & 1 & 0 \\
\hline South Africa & 0 & . & 1 & 1 & 0 & 0 & 0 & 1 \\
\hline Spain & 1 & 0 & 1 & 0 & 0 & 1 & 0 & 1 \\
\hline Sri Lanka & 0 & 1 & 0 & 1 & 0 & 0 & 1 & 0 \\
\hline Sweden & 1 & 0 & 1 & 1 & 0 & 1 & 0 & . \\
\hline Switzerland & 1 & . & 1 & 1 & 0 & 1 & 0 & 1 \\
\hline Syria & 0 & . & 0 & 0 & 0 & 0 & 1 & 1 \\
\hline Tanzania & 0 & 1 & 0 & . & 0 & 1 & 1 & 0 \\
\hline Thailand & 0 & 1 & 0 & 0 & 1 & 1 & 0 & 1 \\
\hline Trinidad-Tobago & 0 & 1 & 1 & 0 & 1 & 0 & 1 & 1 \\
\hline Tunisia & 0 & 1 & 0 & 0 & 0 & 0 & 0 & 1 \\
\hline Turkey & 1 & 1 & 0 & 0 & 0 & 0 & 0 & 0 \\
\hline Uganda & 0 & 0 & 0 & 0 & 0 & 0 & 1 & 0 \\
\hline United Kingdom & 1 & 0 & 1 & 0 & 0 & 1 & 0 & . \\
\hline Uruguay & 0 & . & 1 & 1 & 1 & 0 & 1 & 1 \\
\hline Venezuela & 0 & 1 & 1 & 0 & 1 & 1 & 1 & 0 \\
\hline Zimbabwe & 0 & 1 & 0 & 0 & . & 0 & 1 & 0 \\
\hline
\end{tabular}

NOTES: The classification variables take the value of 1 for countries ranking above the group mean (or median). An exception is OECD, which denotes membership before 1990. If a classification cannot be made due to missing data, this is denoted by ".". The rest of the variables are defined as follows.

UNEQUAL: Gini coefficient of income inequality averaged over 1965 to 1985 . RICH: Average level of GDP per capita from 1960 to 1965. EDUC: Proportion of population of age over 25 that had completed secondary education in 1965. INUS: proportion enrolled in university in the U.S. of total university enrollment abroad by country nationals in 1965. HICORRUS: Contemporaneous correlation between country's growth rate of GDP per capita and that of the U.S. HIVAR: Variance of the growth rate of GDP per capita. HIDEPTH: Financial depth measured by the ratio of M2 to GDP. 


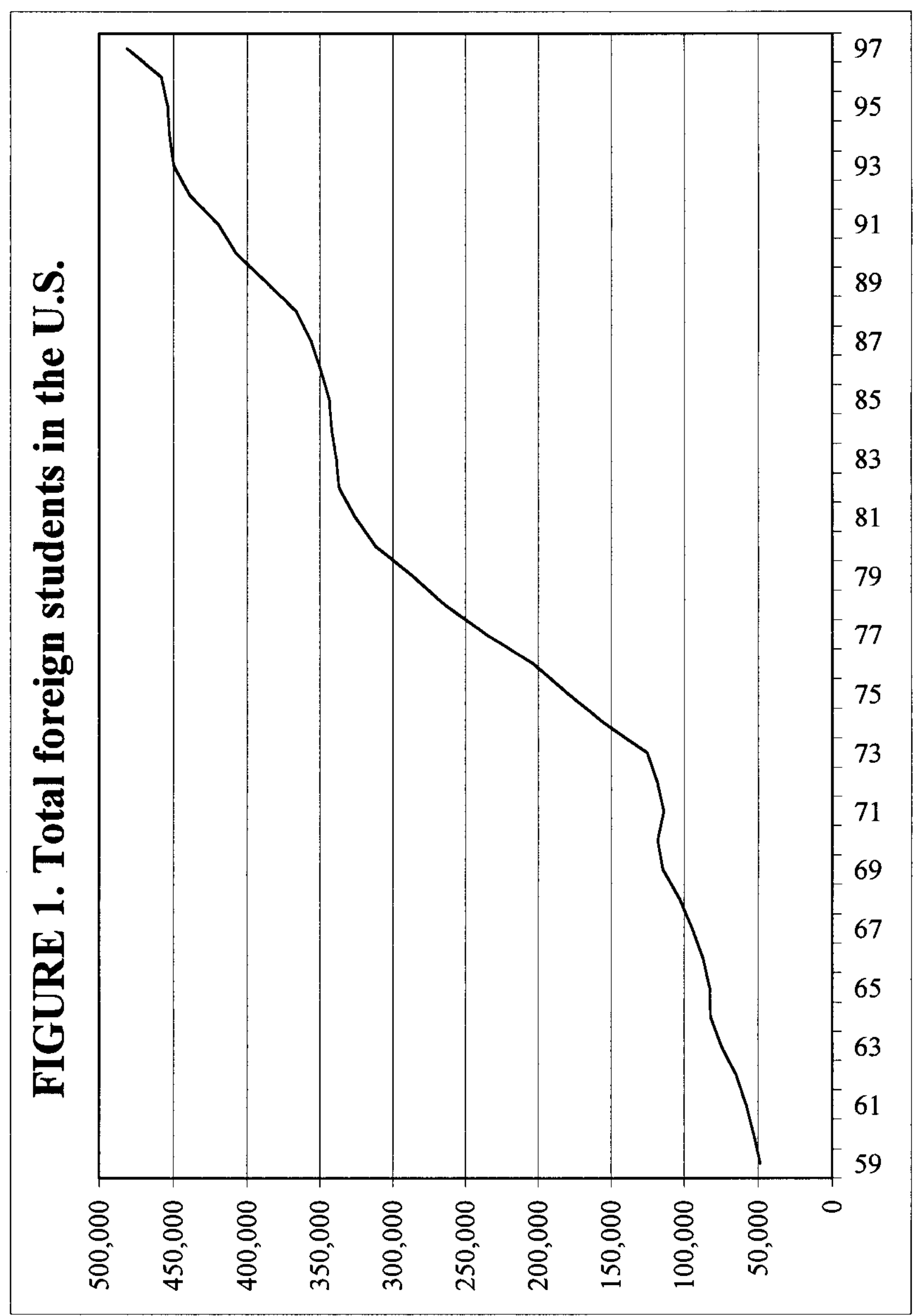




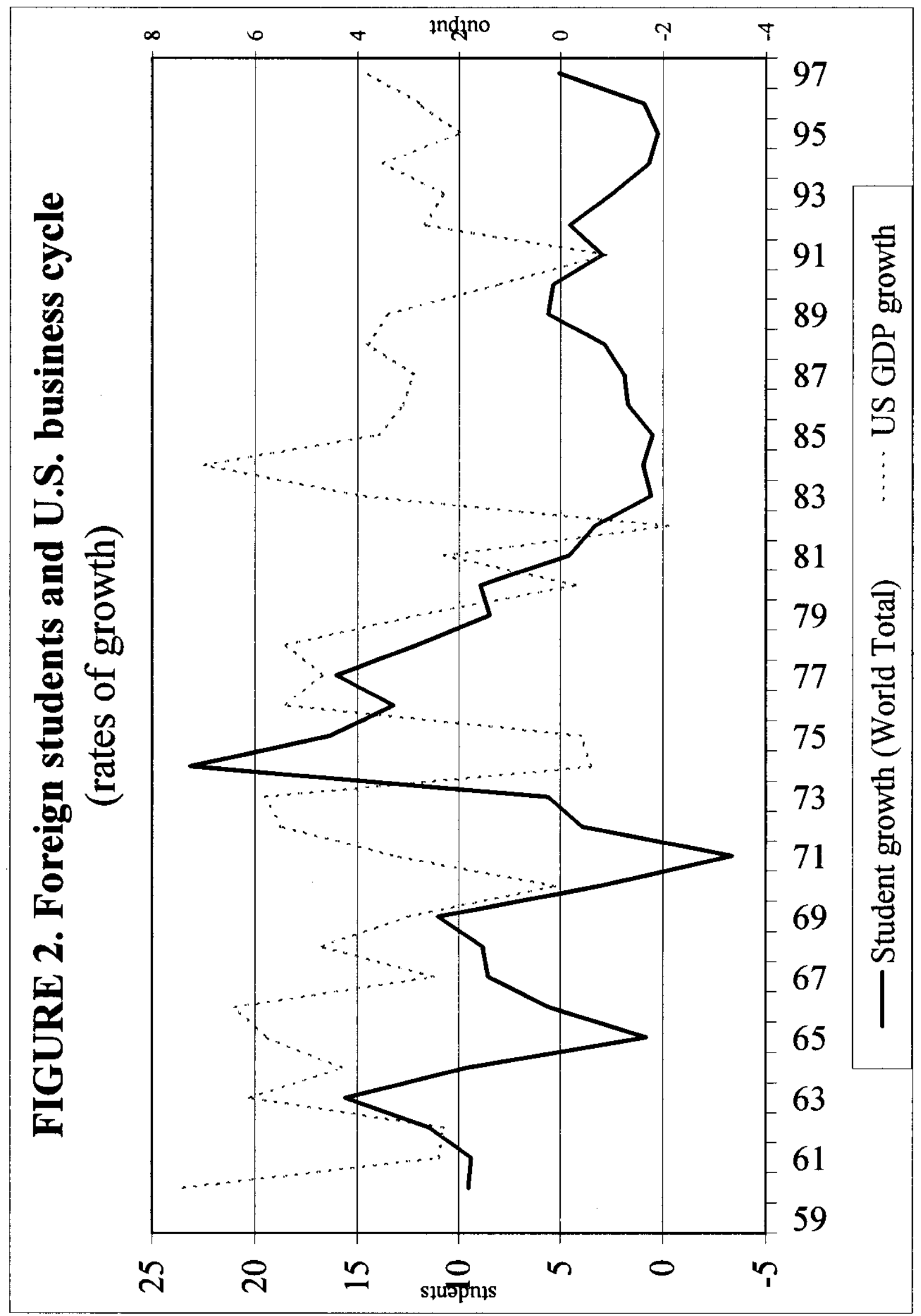




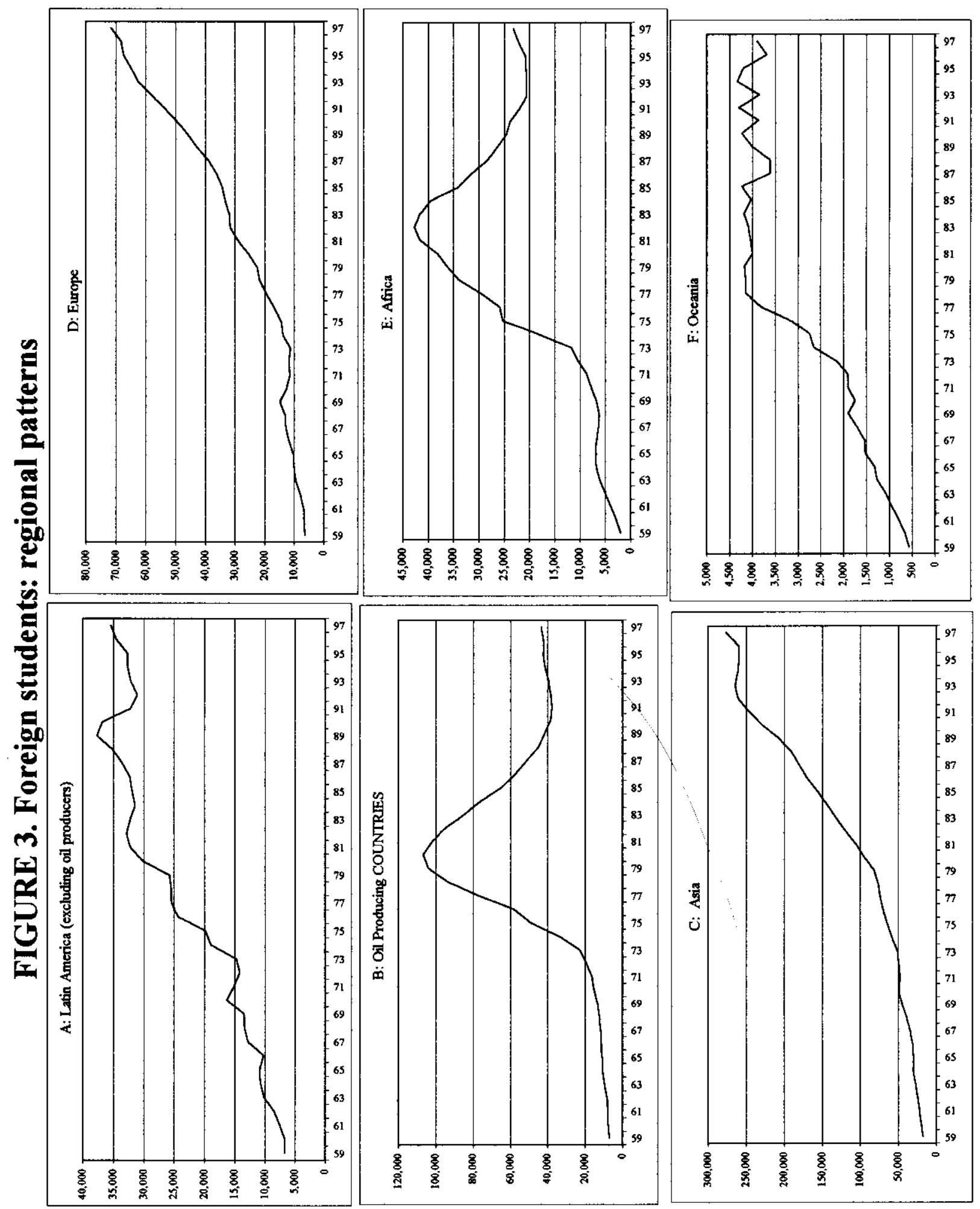


Figure 4. Impulse Responses for all countries
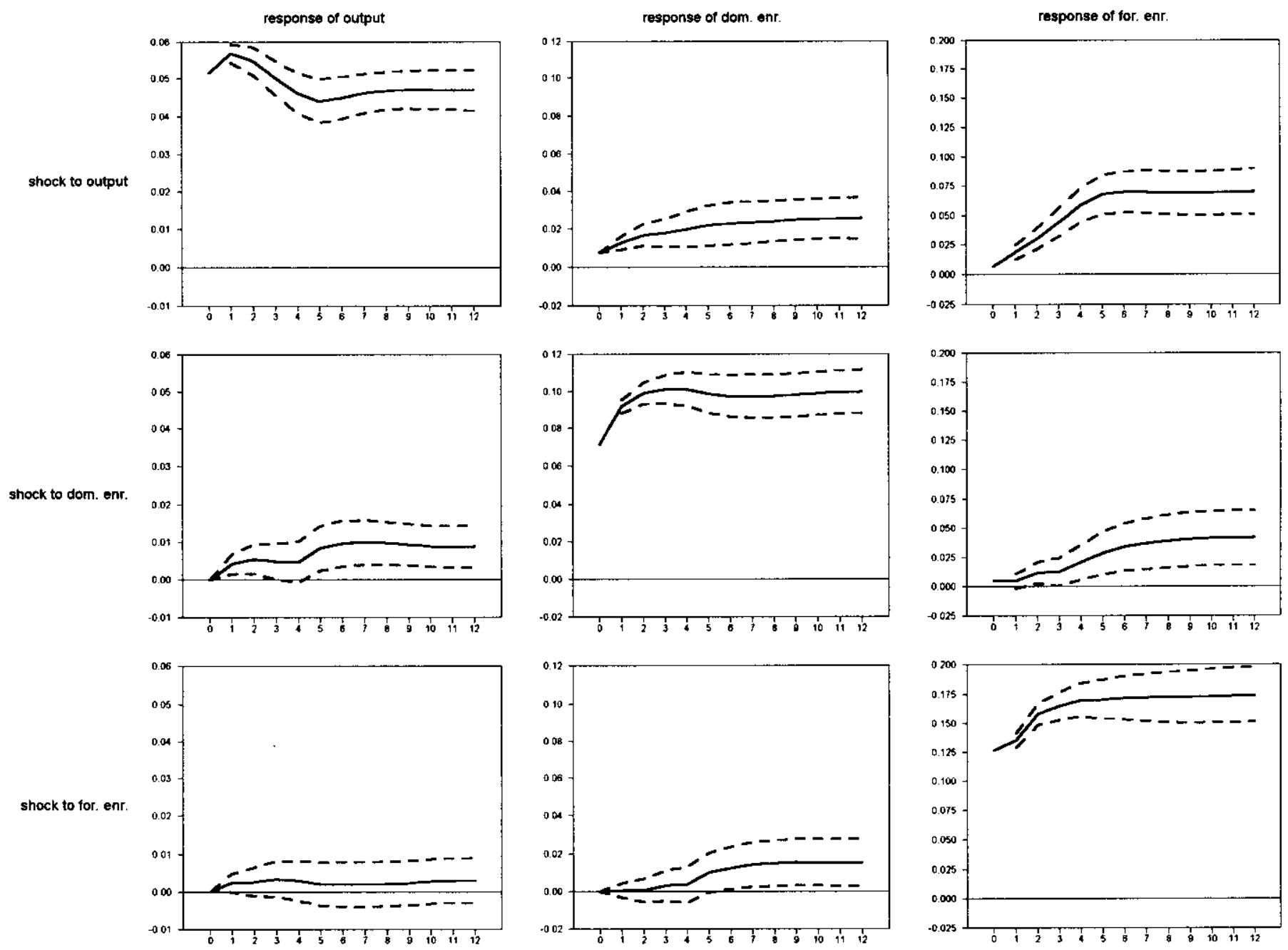
Figure 5. Impulse Responses for OECD countries
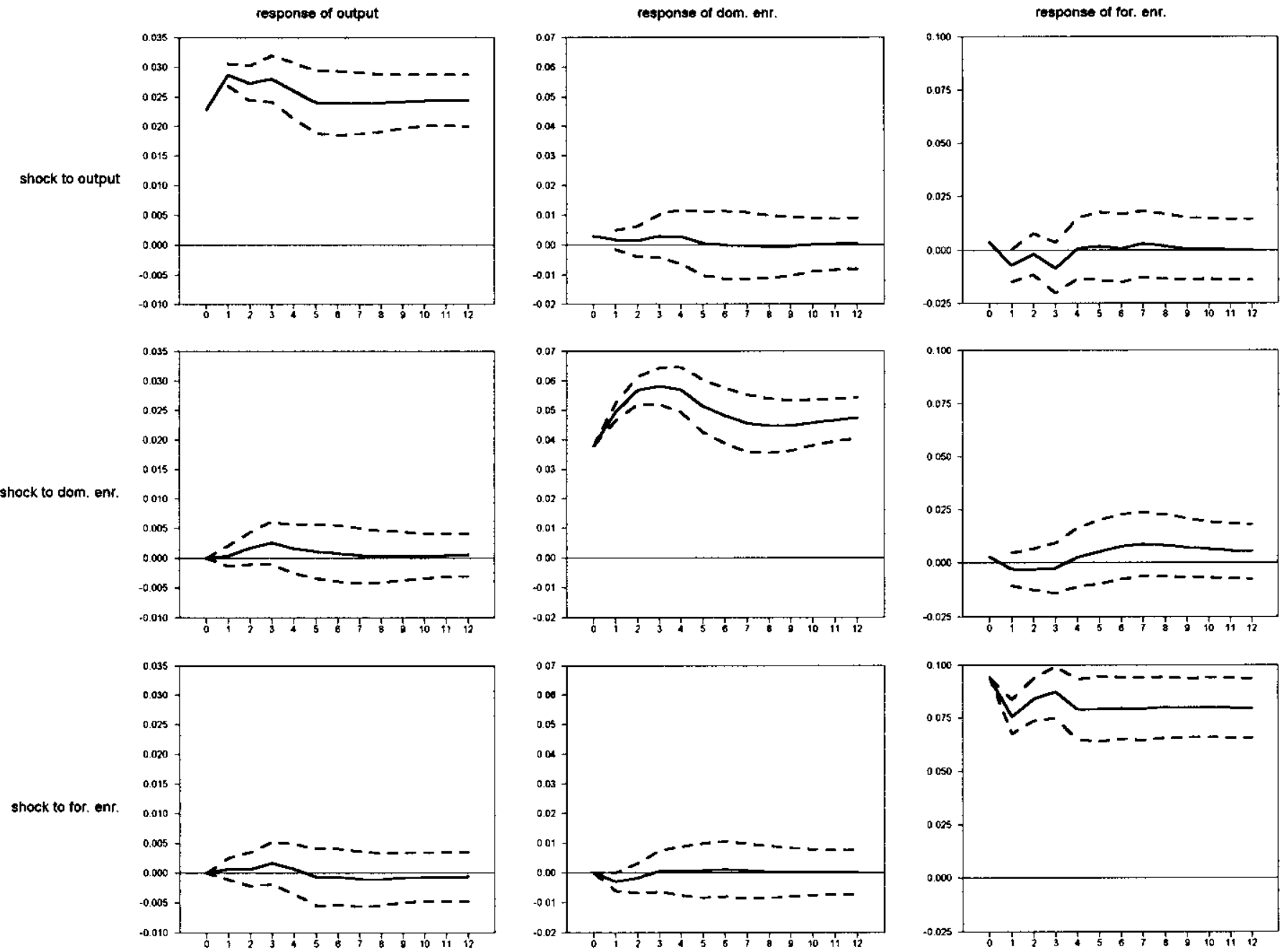
Figure 6. Impulse Responses for non-OECD countries

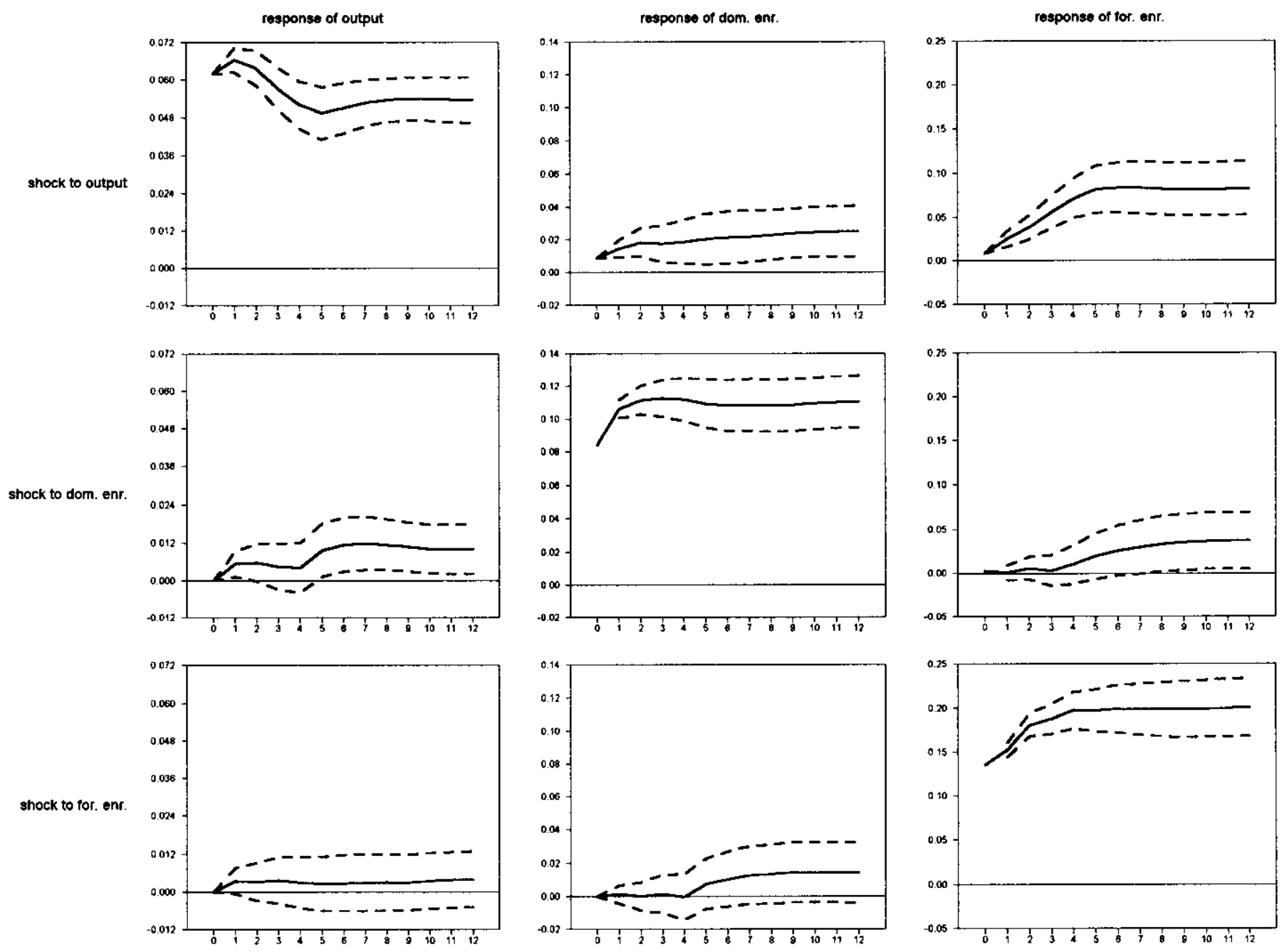

